\title{
PEMBERDAYAAN GURU-GURU MELALUI PEMBUATAN MEDIA AJAR DI PAUD PROVIDENTIA CERIA DESA BATU KECAMATAN LIKUPANG TIMUR
}

\author{
Ferdy Dj. Rorong \\ Universitas Negeri Manado \\ ferdyrorong@unima.ac.id
}

\begin{abstract}
Abstrak
Memilih media yang terbaik untuk tujuan pembelajaran bukanlah pekerjaan yang mudah. karena harus mempertimbangkan berbagai faktor, seperti model pemilihan media dan mengapa pemilihan media itu perlu. Pemilihan media perlu kita lakukan agar kita dapat menentukan media yang terbaik, tepat dan sesuai dengan kebutuhan dan kondisi sasaran didik. Untuk itu, pemilihan jenis media harus dilakukan dengan prosedur yang benar, karena begitu banyak jenis media dengan berbagai kelebihan dan kelemahan masing-masing.

Memilih media hendaknya didasarkan atas kriteria tertentu. Secara umum, kriteria yang harus dipertimbangkan dalam pemilihan media pembelajaran adalah tujuan, sasaran didik, karakteristik media yang bersangkutan, waktu, biaya, ketersediaan, konteks penggunaan, serta mutu teknis. Ada beberapa prinsip umum yang perlu kita perhatikan dalam pemanfaatan media pembelajaran, yaitu: setiap jenis media memiliki kelebihan dan kelemahan, penggunaan beberapa macam media secara bervariasi diperlukan, penggunaan media harus dapat memperlakukan siswa secara aktif. Manfaat praktis media pembelajaran antara lain: media dapat membuat materi pelajaran yang abstrak menjadi lebih konkrit, media juga dapat mengatasi kendala keterbatasan ruang dan waktu, serta media dapat membantu mengatasi keterbatasan indera manusia.

Pembelajaran menyenangkan artinya pembelajaran yang interaktif dan atraktif, sehingga anak didik dapat memusatkan perhatian terhadap pembelajaran yang sedang dijalaninya.

* Kegiatan pengabdian pada masyarakat dalam bentuk pelatihan penggunaan media pembelajaran yang bervariasi kepada Guru-guru Kecamatan remboken telah berhasil dilaksanakan dengan baik.

* Pelaksanaan pelatihan ini telah mencapai tujuan yang dilaksanakan karena semua peserta dapat menguasai dan membuat media pembelajaran yang bervariasi
\end{abstract}

Kata kunci : Media, Bahasa, Pembelajaran,pelatihan 


\section{PENDAHULUAN}

\section{Analisis Situasi}

PAUD adalah suatu wadah pembinaan yang ditujukan kepada anak sejak usia emapt tahun sampai dengan usia enam tahun yang dilakukan melalui pemberian rangsangan pendidikan untuk membantu pertumbuhan dan perkembangan jasmani dan rohani agar anak memiliki kesiapan dalam memasuki pendidikan lebih lanjut. Pada dasarnya ada lima kunci pelayanan anak usia dini yang dapat diidentifikasi di Indonesia.

Usia 4-6 tahun, merupakan masa peka bagi anak. Anak mulai sensitif untuk menerima berbagai upaya perkembangan seluruh potensi anak. Masa peka adalah masa terjadinya pematangan fungsi-fungsi fisik dan psikis yang siap merespon stimulasi yang diberikan oleh lingkungan. Masa ini merupakan masa untuk meletakkan dasar pertama dalam mengembangkan kemampuan fisik, kognitif, bahasa, sosial emosional,konsep diri, disiplin, kemandirian, seni, moral, dan nilainilai agama. Oleh sebab itu dibutuhkan kondisi dan stimulasi yang sesuai dengan kebutuhan anak agar pertumbuhan dan perkembangan anak tercapai secara optimal. Peran pendidik (orang tua, guru, dan orang dewasa lain) sangat diperlukan dalam upaya pengembangan potensi anak 4 - 6 tahun. Upaya pengembangan tersebut harus dilakukan melalui kegiatan bermain sambil belajar atau belajar seraya bermain. Dengan bermain anak memiliki kesempatan untuk bereksplorasi, menemukan, mengekspresikan perasaan, berkreasi, belajar secara menyenangkan. Selain itu bermain membantu anak mengenal dirinya sendiri, orang lain dan lingkungan. Atas dasar hal tersebut di atas, maka kurikulum dikembangkan dan disusun berdasarkan tahap perkembangan anak untuk mengembangkan seluruh potensi anak.

Guru profesional adalah orang yang memiliki kemampuan dan keahlian khusus dalam bidang keguruan sehingga ia mampu melakukan tugas dan fungsinya sebagai guru secara maksimaI. Dengan kata lain guru profesional adalah orang yang terdidik dan terlatih dengan baik serta memiliki pengalaman yang kaya di bidangnya. Yang dimaksud dengan terdidik dan terlatih bukan hanya memilki pendidikan formal tetapi juga harus menguasai berbagai strategi atau teknik dalam KBM serta landasan-landasan kependidikan seperti tercantum dalam kompetensi guru dalam uraian selanjutnya. Dalam melakukan kewenangan profesionalismenya, guru dituntut memiliki seperangkat kemampuan (kompetensi) yang beraneka ragam. Dalam berbagai kasus, kualitas sistem pendidikan secara keseluruhan berkaitan dengan kualitas guru (Beeby, 1969). Untuk itu, peningkatan kualitas pendidikan harus dilakukan melalui upaya peningkatan 
kualitas guru. Secara garis besar, tugas dan tanggung jawab seorang guru adalah mengembangkan kecerdasan yang ada dalam diri setiap anak didiknya. Kecerdasan ini harus dikembangkan agar anak didik dapat tumbuh dan besar menjadi manusia yang cerdas dan siap menghadapi segala tantangan di masa depan. Berhasil atau gagalnya pencapaian tujuan pendidikan tergantung pada proses belajar dan mengajar yang dialami mahasiswa itu disekolah maupun dikeluarga itu sendiri. Belajar merupakan proses dasar dari pada perkembangan hidup manusia. Dengan belajar, manusia melakukan perubahanperubahan kualitatif individu sehingga tingkah lakunya berkembang.semua aktifitas dan prestasi hidup manusia adalah hasil dari belajar. Belajar merupakan sebuah proses dan melalui proses tersebut individu yang melakukan kegiatan belajar memperoleh pengalaman. Oleh karena itu belajar berlangsung secara aktif dengan menggunakan berbagai bentuk perbuatan untuk mencapai suatu tujuan. Media pembelajaran secara umum adalah alat bantu proses belajar mengajar. Segala sesuatu yang dapat dipergunakan untuk merangsang pikiran, perasaan, perhatian dan kemampuan atau keterampilan pembelajar sehingga dapat mendorong terjadinya proses belajar.

\section{Identifikasi dan Perumusan Masalah}

Penggunaan media pembelajaran merupakan salah satu hal yang akan mendukung keberhasilan siswa dalam menguasai materi pelajaran. Berbagai jenis media pembelajaran berbasis tekhnologi informasi dan komunikasi makin berkembang, mulai dari penggunaan komputer, pemanfaatan jaringan internet, pemutaran film untuk beberapa materi pelajaran, dan salah satunya adalah dengan pemanfaatan program Microsoft office powerpoint dalam penyajian materi pelajaran. Dalam upaya peningkatan kualitas pengajaran oleh karena itu para guru harus meningkatkan kualitas pelayanan dengan kesiapan diri dalam pembelajaran yang berbasis ICT (information and Comunication Technology).

\section{TARGET DAN LUARAN}

\section{A. Target :}

Berdasarkan latar belakang pemikiran dan konteks permasalahan yang ada, maka pelaksanaan pelatihan ini bertujuan, terutama untuk menghasilkan pengajar yang berpengetahuan, berkemampuan dan memiliki keterampilan; mengajar yang baik, yang mudah diserap oleh para pembelajar. Menerapkan model-model pengajaran yang koopratif yang mudah diserap oleh pembelajar adalah upaya pengajar untuk mencapai tujuan yang diharapkan yaitu dapat menguasai empat keterampilan berbahasa yakni; keterampilan berbicara, membaca, menulis, menyimak.

\section{B. Luaran}


LModel pembelajaran inovatif ini juga

uaran yang diharapkan melalui pelaksanaan kegiatan pengabdian pada masyarakat ini adalah sebagai berikut :

1. Peningkatan kualitas sumber daya manusia yakni Guru-guru PAUD Providentia Ceria

2. Melalui kegiatan ini diharapkan para Guru-guru PAUD Providentia Ceria dapat memiliki pengetahuan yang positif dalam rangka upaya peningkatan kemampuan Bahasa Jepang Praktis dan mengetahui tulisan hiragana katana yang baik dan benar.

\section{METODE PELAKSANAAN}

\section{A. Metode Kegiatan}

Pelaksanaan Iptek pada masyarakat ini adalah workshop pembelajaran Bahasa Jepang praktis dan pengenalan Huruf Jepang dengan menggunakan metode pembelajaran active learning dengan menggunakan multimedia.. Kegiatan ini bertujuan untuk membekali pengetahuan pembelajaran bahasa Jepang praktis dan huruf Jepang yang efektif. Sehingga ketika timbul permasalahan-permasalahan dalam proses pembelajaran para pengajar dapat mengatasi. Berdasarkan permasalahan di atas sehingga workshop bagi guru-guru PAUD Providentia Ceria Desa Batu Kecamatan Likupang Timur

\section{B. Prosedur Pelaksanaan}

memeri manfaat khusus bagi pengajar, karena dengan menggunakan model pembelajaran ini, Cara mengajar yang menarik akan membuat Ibu-ibu tidak bosan, oleh sebab itu pengajar harus pandai memilih media pengajaran yang tepat. Sebab penggunaan media pengajaran yang tepat memegang peranan penting sebagai alat yang dapat mendorong minat belajar serta dapat memberikan stimulus pada indra peserta didik. Menurut Ali (2004:53), "Media pembelajaran diartikan sebagai segala sesuatu yang dapat digunakan untuk menyalurkan pesan (message), menstimulasi pikiran, perasaan, perhatian dan kemauan siswa sehingga dapat membantu kelancaran, efektivitas dan efisiensi pembelajaran".

\section{HASIL DAN PEMBAHASAN}

Kegiatan ini dilaksanakan pada tanggal 9-10 Januari 2019 dan diikuti oleh seluruh Guru-guru PAUD PROVENTIA CERIA di Desa Batu. Dalam pemilihan media seorang pendidik diharapakan pandaipandai memilih dan memilah media yang akan digunakan dalam kegiatan belajar mengajar. Media pembelajaran yang akan digunakan harus menyesuaikan dengan umur siswa, keadaan siswa, situasi lingkunan belajar siswa, kemampuan siswa, dan waktu yang tepat.

Prinsip-prinsip Pemanfaatan Media 
da beberapa prinsip umum yang perlu kita perhatikan dalam pemanfaatan media pembelajaran, yaitu:

1. Setiap jenis media, memiliki kelebihan dan kelemahan

Tidak ada satu jenis media yang cocok untuk semua proses pembelajaran dan dapat mencapai semua tujuan belajar. lbaratnya, tak ada satu jenis obat yang manjur untuk semua jenis penyakit.

2. Penggunaan beberapa macam media secara bervariasi memang diperlukan Namun harap diingat, bahwa penggunaan media yang terlalu banyak sekaligus dalam suatu kegiatan pembelajaran, justru akan membingungkan siswa dan tidak akan memperjelas pelajaran. Oleh karena itu gunakan media seperlunya, jangan berlebihan.

3. Penggunaan media harus dapat memperlakukan siswa secara aktif. Lebih baik menggunakan media yang sederhana yang dapat mengaktifkan seluruh siswa daripada media canggih namun justru membuat siswa kita terheran-heran pasif.

Sebelum media digunakan harus direncanakan secara matang dalam penyusunan rencana pembelajaran.

Tentukan bagian materi mana saja yang akan kita sajikan dengan bantuan media. Rencanakan bagaimana strategi dan
tekiAik penggunaannya. Hindari penggunaan media yang hanya dimaksudkan sebagai selingan atau sekedar pengisi waktu kosong saja. Jika siswa sadar bahwa media yang digunakan hanya untuk mengisi waktu kosong, maka kesan ini akan selalu muncul setiap kali guru menggunakan media. Penggunaaan media yang sembarangan, asal-asalan, atau "daripada tidak dipakai", akan membawa akibat negatif yang lebih buruk. Harus senantiasa dilakukan persiapan yang cukup sebelum penggunaaan media. Kurangnya persiapan bukan saja membuat proses pembelajaran tidak efektif dan efisien, tetapi justru mengganggu kelancaran proses pembelajaran. Hal ini terutama perlu diperhatikan ketika kita akan menggunakan media elektronik.

Manfaat Praktis Media dalam Pembelajaran

Selain beberapa manfaat media seperti yang dikemukakan oleh Kemp dan Dayton tersebut, kita. masih dapat menemukan banyak manfaat-manfaat praktis yang lain. Manfaat praktis media pembelajaran antara lain:

1. Media dapat membuat materi pelajaran yang abstrak menjadi lebih konkrit

Arus listrik misalnya dapat dijelaskan melalui media grafis berupa simbol-simbol dan bagan. Demikian 
pula materi pelajaran yang rumit dapat disajikan secara lebih sederhana dengan bantuan media. Misalnya materi yang membahas rangkaian peralatan elektronik atau mesin dapat disederhanakan melalui bagan skema yang sederhana.

2. Media juga dapat mengatasi kendala keterbatasan ruang dan waktu Sesuatu yang terjadi di luar ruang kelas, bahkan di luar angkasa dapat dihadirkan di dalam kelas melalui bantuan media. Demikian pula beberapa peristiwa yang telah terjadi di masa lampau, dapat kita sajikan di depan siswa sewaktu-waktu. Dengan media pula suatu peristiwa penting yang sedang terjadi di benua lain dapat dihadirkan seketika di ruang kelas.

3. Media dapat membantu mengatasi keterbatasan indera manusia Obyek-obyek pelajaran yang terlalu kecil, terlalu besar atau terlalu jauh, dapat kita pelajari melalui bantuan media. Demikian pula obyek berupa proses/kejadian yang sangat cepat atau sangat lambat, dapat kita saksikan dengan jelas melalui media, dengan cara memperlambat, atau mempercepat kejadian. Misalnya, proses perkembangan janin dalam kandungan selama sembilan bulan, dapat dipercepat dan disaksikan melalui media hanya dalam waktu beberapa menit saja. Sebaliknya, ketika anak belajar teknik menendang bola atau melakukan smash permainan bulu tangkis yang sangat cepat, dapat dipelajari dengan cara memperlambat gerakan tersebut melalui bantuan media (slow motion). Media juga dapat menyajikan obyek pelajaran berupa benda atau peristiwa langka dan berbahaya ke dalam kelas. Peristiwa terjadinya gerhana matahari total yang jarang sekali terjadi, dapat disaksikan oleh siswa setiap saat melalui media rekaman. Terjadinya gunung meletus yang berbahaya dapat pula disaksikan siswa di kelas melalui media. Informasi pelajaran yang disajikan dengan media yang tepat akan memberikan kesan mendalam dan lebih lama tersimpan pada diri siswa.

\section{KESIMPULAN DAN SARAN}

\section{Kesimpulan}

Memilih media yang terbaik untuk tujuan pembelajaran bukanlah pekerjaan yang mudah. karena harus mempertimbangkan berbagai faktor, seperti model pemilihan media dan mengapa pemilihan media itu perlu. Pemilihan media perlu kita lakukan agar kita dapat menentukan media yang terbaik, tepat dan sesuai dengan kebutuhan dan kondisi sasaran didik. Untuk itu, pemilihan jenis 
media harus dilakukan dengan prosedur yang benar, karena begitu banyak jenis media dengan berbagai kelebihan dan kelemahan masing-masing.

Memilih media hendaknya didasarkan atas kriteria tertentu. Secara umum, kriteria yang harus dipertimbangkan dalam pemilihan media pembelajaran adalah tujuan, sasaran didik, karakteristik media yang bersangkutan, waktu, biaya, ketersediaan, konteks penggunaan, serta mutu teknis. Ada beberapa prinsip umum yang perlu kita perhatikan dalam pemanfaatan media pembelajaran, yaitu: setiap jenis media memiliki kelebihan dan kelemahan, penggunaan beberapa macam media secara bervariasi diperlukan, penggunaan media harus dapat memperlakukan siswa secara aktif. Manfaat praktis media pembelajaran antara lain: media dapat membuat materi pelajaran yang abstrak menjadi lebih konkrit, media juga dapat mengatasi kendala keterbatasan ruang dan waktu, serta media dapat membantu mengatasi keterbatasan indera manusia.

Pembelajaran menyenangkan artinya pembelajaran yang interaktif dan atraktif, sehingga anak didik dapat memusatkan perhatian terhadap pembelajaran yang sedang dijalaninya.

* Kegiatan pengabdian pada masyarakat dalam bentuk pelatihan penggunaan media pembelajaran yang bervariasi kepada Guru-guru
Kecamatan remboken telah berhasil dilaksanakan dengan baik.

* Pelaksanaan pelatihan ini telah mencapai tujuan yang dilaksanakan karena semua peserta dapat menguasai dan membuat media pembelajaran yang bervariasi

\section{B.Saran}

Dengan melihat keberhasilan yang diperoleh serta animo masyarakat/peserta maka disarankan agar kegiatan pengabdian pada masyarakat dalam bentuk pelatihan berupa kusus singkat seperti ini perlu ditindak lanjuti pada lokasi yang sama maupun lokasi yang lain dengan topic/materi yang berbeda. Mengapa dikatakan demikian karena hal ini dapat meningkatkan rasa percaya diri terutama bagi para guru sehingga menjadi guru yang profesional dalam mengajar di depan kelas.

\section{KEPUSTAKAAN}

Azwar Saifuddin. 1999. Metode Penelitian, Yogyakarta: Pustaka Pelajar.

\section{Arikunto, Suharsimi, 1998. Prosedur}

\section{Penelitian: Suatu Pendekatan}

Praktek, Jakarta: PT Rineka Cipta.

Chandra. T 2000. Mengenal Kosa kata bahasa Jepang, Jakarta : Evergreen Japanese Course

Dwiloka Bambang, Riana Rati. 2005.

Teknik Menulis Karya Ilmiah, Jakarta: Rineka Cipta. 
Jurnal ABDIMAS, Vol. 12, No. 1, April 2019

ISSN: 1979-0953 | e-ISSN: 2598-6066

Hartanto, B., \& Wijaya, 2004. F., The Magic

Widodo, Edi. 2006. Multimedia dan of Flash MX 2004, Jakarta: PT. Elex Pembelajaran Bahasa. Bandung Media Komputindo

Sadewa, Yoel, 2004 Bahasa Jepang Yang Mudah Yasahii Nihongo, Media Abadi, Yogyakarta 